\title{
Evaluation of the Effects of Various Factors on the Serum Cholinesterase Activity Level
}

\author{
Masahide IMAKI*, Miho OHGURI*, Akio IUCHI** \\ Yukie YOSHIDA* and Seiki TANADA**
}

\section{Introduction}

As we become increasingly aware of the serious effects of our life style on our health condition, new theoretical bases must be established for preventive medicine and health promotion. With such a background, mass examinations planned for area residents are becoming part of routine health care practice and these examinations are being increasingly better organized. Within this diagnostic system, the blood chemical analyses are important. From the viewpoint of preventive medicine, we believe that it would be highly advantageous if these tests are used not only to screen for diseases but also as indices for health guidance of normal individuals (Higuch et al., 1994; Imaki et al. 1993). From this viewpoint, in the present study, we studied the appropriateness of serum cholinesterase activity as a health index.

Since the importation of parathion into Japan in 1951, this organophosphte agent, together with organochlorine preparations, have been used in enormous quantities as a leading insecticide. Subsequently, frequent incidence of toxicoses associated with this and related agents have been reported, which resulted in active studies on the methods for the diagnosis of intoxication by various types of organophosphate agents (Cucuianu et al., 1975; Higashi et al., 1985). These agents potently inhibit cholinesterase and determining the activity of this enzyme has become a significant means for the diagnosis of intoxication by organophosphate agents (Nakamura, 1989).

The serum level of this enzyme is determined in clinical diagnoses of conditions such as hepatic diseases, hypertension, diabetes mellitus, and anemia. Shibata (1970) reported that the serum cholinesterase activity level is reduced when a patient is unable to eat due to malnutrition or esophageal stenosis and that this reduction parallels a reduction in the blood hemoglobin level, an important indicator of nutritional status. In an epidemiological survery conducted by Hirai (1976) in agricultural villages, the relationship between the serum cholinesterase activity level and factors related to food habit was reported. In addition, there are reports on the relationship between the serum cholinesterase activity level and physical activity (Pawlowska et al., 1985; Ryhanen et al., 1988; Vihko et al., 1979).

In the present study, we focused on the relationship among the results of various blood chemical analyses, hemodynamic

\footnotetext{
* 大阪府立看護大学医療技術短期大学部臨床栄養学科

** 徳島大学医学部公衆衛生学講座

* Department of Clinical Nutrition, Osaka Prefectural College of Health Science

** Department of Public Health, School of Medicine, The University of Tokushima
} 
data, posture, nutritional state, daily physical activity, and mild exercises.

\section{Subject and Methods}

1. Relationship between serum cholinesterase activity and various factors in epidemiological study

\section{1) Subjects}

The subjects study were of the same sex and age to reduce complications from other factors. First 265 healthy female students at the college for Dietitians were examined. Of the students, the 252 who met the following conditions of health were included in the study.

(1) Those who were not under medical treatment.

(2) Those who did not have a past history of cardiac or hepatobiliary disease, and who had no abnormal subjective symptoms.

(3) Those who did not exhibit abnormalities such as in blood pressure in routine physical examinations.

(4) Those who did not exhibit abnormalities in liver function tests.

(5) Those who were not engaged in particularly demanding physical activities.

(6) Those who followed our instructions in the survey nutritional intake and life style.

The physical characteristics of the subjects are given in Table 1 . The physical characteristics data gave results within normal ranges.

2) Nutritional survey

A nutritional survey was performed by the method of individual entry into survery sheets. For collection of data on types and quantities of food consumed, an instruction sheet on how to fill out the form and detailed examples were distributed to the
Table 1 Physical charcteristics of all subjects

\begin{tabular}{lrrrr}
\hline \multicolumn{1}{c}{ Items } & Mean & S.E. & Max. & \multicolumn{1}{c}{ Min. } \\
\hline Age (year) & 21.3 & 0.21 & 22.0 & 20.0 \\
Height $(\mathrm{cm})$ & 158.0 & 0.32 & 171.0 & 141.0 \\
Weight $(\mathrm{kg})$ & 52.2 & 0.39 & 89.0 & 40.0 \\
BMI $\left(\mathrm{kg} / \mathrm{m}^{2}\right)$ & 20.9 & 0.14 & 33.4 & 16.4 \\
\hline
\end{tabular}

Number of subjects : 252

BMI : Body mass index

subjects, together with a $1 \mathrm{~kg}$ spring scale so that each individual could weight her food before (if possible) or after it was cooked. To assure data accuracy, actual photographs of food, utensils, and measuring instruments were used, and the names and weights of foods were determined in an interview of each subject with an experienced dietitian. The survey was conducted for three consecutive days and the mean values obtained were used as those for the food intake of each subject. The 4 th edition of the Food Component Table was used to compute the energy and nutritional values of foods. The vitamin $\mathrm{C}$ intake was computed, assuming that half was lost during cooking.

3) Time study

Daily activities of the subjects were recorded for three consecutive days, excluding weekends and holidays. During this period, the subjects were asked to record details of specific life activities and their time schedule in a questionnaire. The time-activity record was a so-called "simplified time study". Instead of having an observer record minute detalis and the time of a daily activity, respondents themselves recorded the time they began and completed their activities, the time it took to complete them and their nature. A time sequence of 72 hours in 5-minute increments was printed on 
the questionnaire. Participants simply checked off the time they began or concluded a specific activity. If desired, they could record its nature later. Based on the records of activities in 72 hour periods, according to the book published by the Ministry of Health and Welfare of Japan (1989), the RMR (Relative Metabolic Rate) was applied to each hour of activity and the energy expended in one day was calculated. The values used as individual basal metabolic rates were corrected methods for weight for individuals whose weights were far from the proposed standard outlined in the "Recommended Dietary Allowances for the Japanese (Fourth Revision)" (1989).

4) Measurement of serum cholinesterase activity

Venous blood samples were usually drawn from subjects after they had fasted overnight for at least $12 \mathrm{hr}$. The seurm was separated and stored at $4^{\circ} \mathrm{C}$ for analysis. Serum cholinesterase activity was determined by a Cholinesterase B Test Wako Kit (Wako Pure chemical Industries) using a Hitachi Spectrophotometer at $505 \mathrm{~nm}$ (Kalow et al., 1957).

Serum GOT, GPT, LDH, $\gamma$-GTP, total cholesterol, free cholesterol, HDL-cholesterol, phospholipid, triglyceride, $\mathrm{Fe}, \mathrm{Ca}$ and $\mathrm{Mg}$ were also measured with the Wako test.

5) Determination of the blood pressure and blood circulatory dynamics tests

As for blood pressure and blood circulatory dynamics tests, Pulse wave-Korokoff sound recorder model GP303S of paramatech Corp. was used.

6) Statistical analyses

Data were analyzed by the SPSS (Statisti- cal Package for the Social Science) procedure. Mean differences between two groups were analyzed by the Mann-Whitney U Test and multiple regression analysis by forward selection. The standard of FIN (Selection) and Fout (Removal) was set at 2.0.

2. Experiment on the effect of light exercise

Three groups of healthy young women were given exercise regimens of different intensities for 6 weeks, and their serum cholinesterase activity was determined before and after the test.

1) Subjects

The test subjects, 24 healthy young women, were divided into 3 groups of 6 women each. These subjects were 24 of the 252 women selected for the cross-sectional survery.

2) Exercise regimens

A bicycle ergometer was used. Amounts of exercise corresponding to 30,50 , and $70 \%$ of the maximum oxygen uptake were imposed for 10, 20, and 30 minutes, respectively, 3 times a week for 6 weeks.

3) Measurement of serum cholinesterase activity

Serum cholinesterase activity was measured in the same way as in the epidemiological study.

\section{Results}

1. Relationships of nutritional intake energy expenditure and life style with the serum cholinesterase activity

1) Distribution of serum cholinesterase activity levels

Fig. 1. shows the distribution of serum cholinesterase activity levels in the 252 women selected for study. The mean 


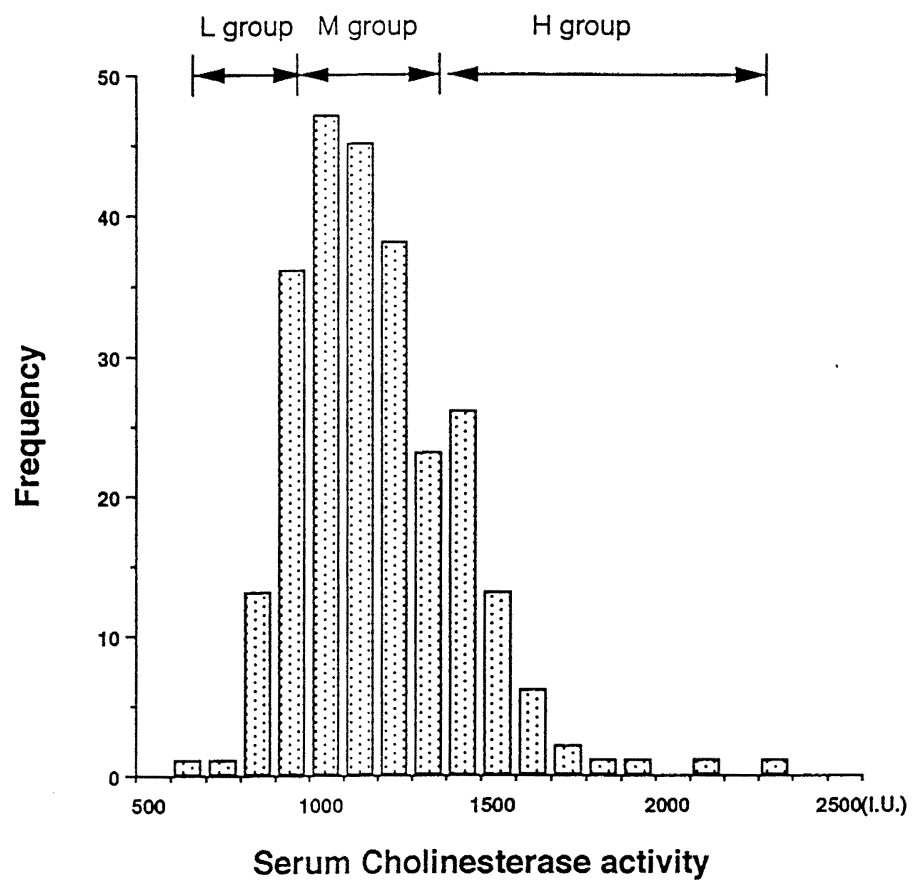

Fig. 1 Distribution of serum cholinesterase activity

level \pm S.D. was $1188.2 \pm 209.1$ units, and levels showed a log normal distribution $\{\mathrm{L}$ (Low) group 979 units, M (Middle) group 980 1378 units, $\mathrm{H}$ (High) group 1379 units $\sim)$.

2) Nutritional intake and energy expenditure of the subjects

Data on the nutritional intakes and energy expenditures of the test subjects are shown in Table 2 . Only the protein intake was higher than the nutritional requirement for women in their 20's, who normally have a relatively low exercise level, while other energy values and the iron and $\mathrm{Ca}$ intakes were lower. The energy expenditure exceeded the energy intake.

3) The relationship between serum cholinesterase activity and blood chemical test

Table 3 shows the relationship between
Table 2 Mean of nutrient intake and physical activity

\begin{tabular}{lc}
\hline \multicolumn{1}{c}{ Variable } & \\
\hline Nutrient intake & $1,702.2 \pm 36.2 \#$ \\
Energy (kcal/day) & $64.8 \pm 1.5$ \\
Protein (g/day) & $50.0 \pm 1.3$ \\
Fat (g/day) & $241.8 \pm 5.8$ \\
Carbohydrate (g/day) & $429.7 \pm 13.9$ \\
Calcium (mg/day) & $2,391.1 \pm 241.8$ \\
Vitamin A (I.U.) & $0.9 \pm 0.02$ \\
Vitamin $\mathrm{B}_{1}$ (mg/day) & $1.1 \pm 0.03$ \\
Vitamin $\mathrm{B}_{2}$ (mg/day) & $103.5 \pm 5.4$ \\
Vitamin C (mg/day) & \\
\hline Physical activity & $2,065.8 \pm 23.9$ \\
Energy expenditure & $39.3 \pm 0.45$ \\
(kcal/day) & \\
Energy expenditure & \\
per body weight (kcal/day) & \\
\hline \#: Values are mean + S.E.
\end{tabular}

serum cholinesterase activity and blood chemical test. The $\mathrm{H}$ group had significantly high serum total cholesterol, free cholesterol, triglyceride, phospholipid levels than 
Table 3 Comparison of blood chemical test with serum cholinesterase activity levels

\begin{tabular}{|c|c|c|c|c|c|}
\hline & \multicolumn{4}{|c|}{ Serum cholinesterase activity } & \multirow{3}{*}{$\mathrm{p} \cdot$ Value } \\
\hline & \multicolumn{2}{|c|}{ L group } & \multicolumn{2}{|c|}{ H group } & \\
\hline & Mean & S.E. & Mean & S.E. & \\
\hline GOT (Karmen units) & 10.6 & 0.67 & 11.7 & 0.76 & 0.139 \\
\hline GPT (Karmen units) & 4.6 & 0.33 & 6.0 & 0.68 & 0.467 \\
\hline $\mathrm{LDH}(\mathrm{U} / l)$ & 331.5 & 9.55 & 346.6 & 59.8 & 0.116 \\
\hline$\gamma \cdot \mathrm{GTP}(\mathrm{U} / l)$ & 8.4 & 0.56 & 11.3 & 8.30 & 0.002 \\
\hline $\mathrm{CPK}(\mathrm{IU} / l)$ & 55.5 & 4.63 & 61.0 & 5.52 & 0.281 \\
\hline Total cholesterol (mg/dl) & 156.7 & 4.72 & 176.8 & 7.66 & 0.001 \\
\hline Free cholestrol $(\mathrm{mg} / \mathrm{dl})$ & 41.3 & 1.12 & 44.5 & 1.05 & 0.020 \\
\hline HDL cholesterol (mg/dl) & 53.2 & 1.75 & 50.2 & 1.59 & 0.110 \\
\hline Triglyceride (mg/dl) & 58.4 & 3.09 & 84.9 & 5.34 & 0.000 \\
\hline Phospholipids (mg/dl) & 179.2 & 4.46 & 188.5 & 3.45 & 0.049 \\
\hline $\mathrm{Fe}(\mu \mathrm{g} / \mathrm{dl})$ & 113.8 & 9.46 & 134.7 & 9.15 & 0.059 \\
\hline $\mathrm{Ca}(\mathrm{mg} / \mathrm{dl})$ & 9.1 & 0.23 & 9.7 & 1.66 & 0.094 \\
\hline $\mathrm{Mg}(\mathrm{mg} / \mathrm{dl})$ & 2.1 & 0.03 & 2.1 & 0.02 & 0.228 \\
\hline
\end{tabular}

Number of subjects: L group 42, H group 52

Table 4 Comparison of blood pressure and blood circulatory dynamic test with serum cholinesterase activity levels

\begin{tabular}{|c|c|c|c|c|c|}
\hline & \multicolumn{4}{|c|}{ Serum cholinesterase activity } & \multirow{3}{*}{$\mathrm{p}$-Value } \\
\hline & \multicolumn{2}{|c|}{ L group } & \multicolumn{2}{|c|}{$\mathrm{H}$ group } & \\
\hline & Mean & S.E. & Mean & S.E. & \\
\hline Systolic pressure $(\mathrm{mmHg})$ & 115.1 & 1.53 & 112.3 & 1.23 & 0.08 \\
\hline Diastolic pressure $(\mathrm{mmHg})$ & 74.9 & 1.26 & 73.0 & 1.13 & 0.19 \\
\hline $\begin{array}{l}\text { Pulse wave to korotkoff sound } \\
\text { time (msec) }\end{array}$ & 4.4 & 0.06 & 4.3 & 0.04 & 0.01 \\
\hline Cardiac output $(l / \mathrm{min})$ & 3.0 & 0.12 & 3.1 & 0.11 & 0.36 \\
\hline Pressure rate product $\left(\mathrm{O}^{2} \mathrm{mg}\right)$ & $8,372.7$ & 277.1 & $8,000.8$ & 185.7 & 0.13 \\
\hline $\begin{array}{l}\text { Total peripheral resister } \\
(\text { dyne } / \mathrm{sec} / \mathrm{cm})\end{array}$ & $1,659.1$ & 65.5 & $1,618.2$ & 60.3 & 0.32 \\
\hline
\end{tabular}

Number of subjects: L group 42, H group 52

those with L group. There was significant difference between $\gamma$-GTP in serum enzyme activity of $\mathrm{L}$ group and $\mathrm{H}$ group.

4) The relationship between sreum cholinesterase activty and blood pressure and blood circulatory dynamics tests

Table 4 shows the relationship between serum cholinesterase activity and blood pressure and blood circulatory dynamics tests. There were significant differences between pulse wave to korotkoff sound time level of $\mathrm{L}$ group and $\mathrm{H}$ group.

5) The relatioship between serum cholinesterase activity and nutrient intake

Table 5 shows the results of multiple regression analysis by the forward selection method, using energy and major nutrient intakes (protein, fat, carbohydrate, $\mathrm{Ca}, \mathrm{K}$, $\mathrm{Fe}$, Vitamin $\mathrm{A}, \mathrm{B}_{1}, \mathrm{~B}_{2}$, and $\mathrm{C}$ ) serum cholinesterase activity as the target variable. The food components selected for evaluation were protein and Vitamin $\mathrm{B}_{2}$, of 
Table 5 Results of multiple regression analysis for explaining serum cholinesterase activity

\begin{tabular}{lcr}
\hline Selected variable & $\begin{array}{c}\text { Standard partial } \\
\text { regression } \\
\text { coefficient }\end{array}$ & F-value \\
\hline Protein & 0.358 & $10.7^{*}$ \\
Vitamin $\mathrm{B}_{2}$ & -0.345 & $9.9^{*}$ \\
\hline Multiple correlation & 0.299 & \\
$\quad$ coefficient (R) & $6.31^{*}$ & \\
F.value & & \\
\hline$*: \mathrm{p}<0.01$ &
\end{tabular}

which protein showed the highest standard partial regression coefficient. In other words, protein intake was most closely correlated with the serum cholinesterase activity.

6) Serum cholinesterase activity and life style

Table 6 shows the relationships between
Table 6 Relationship between lifestyle and serum cholinesterase activity

\begin{tabular}{crc}
\hline & $\mathrm{N}$ & $\begin{array}{c}\text { Serum cholinesterase } \\
\text { activity }\end{array}$ \\
\hline \multicolumn{2}{c}{ Cigarettes per day } & \\
0 & 219 & $1,190.6 \pm 14.1$ \\
$\geqq 1$ & 33 & $1,172.7 \pm 37.2$ \\
Alcohol (ml) per week & \\
0 & 179 & $1,181.1 \pm 15.7$ \\
$\geqq 1$ & 73 & $1,205.7 \pm 24.2$ \\
Body mass index $\left(\mathrm{kg} / \mathrm{m}^{2}\right)$ & \\
$<22.0$ & 189 & $1,160.9 \pm 14.3^{*}$ \\
$\geqq 22.0$ & 63 & $1,270.2 \pm 28.0$ \\
\hline
\end{tabular}

$\mathrm{N}:$ Number of subjects ${ }^{*}: \mathrm{p}<0.05,{ }^{* *}: \mathrm{p}<0.01$ Values are mean \pm S.E.

the serum cholinesterase activity and life style. The percentage of smokers was $13.0 \%$. There was no significant difference between the serum cholinesterase activity levels of smokers and non-smokers. Among the test subjects, $28.9 \%$ drank alcoholic

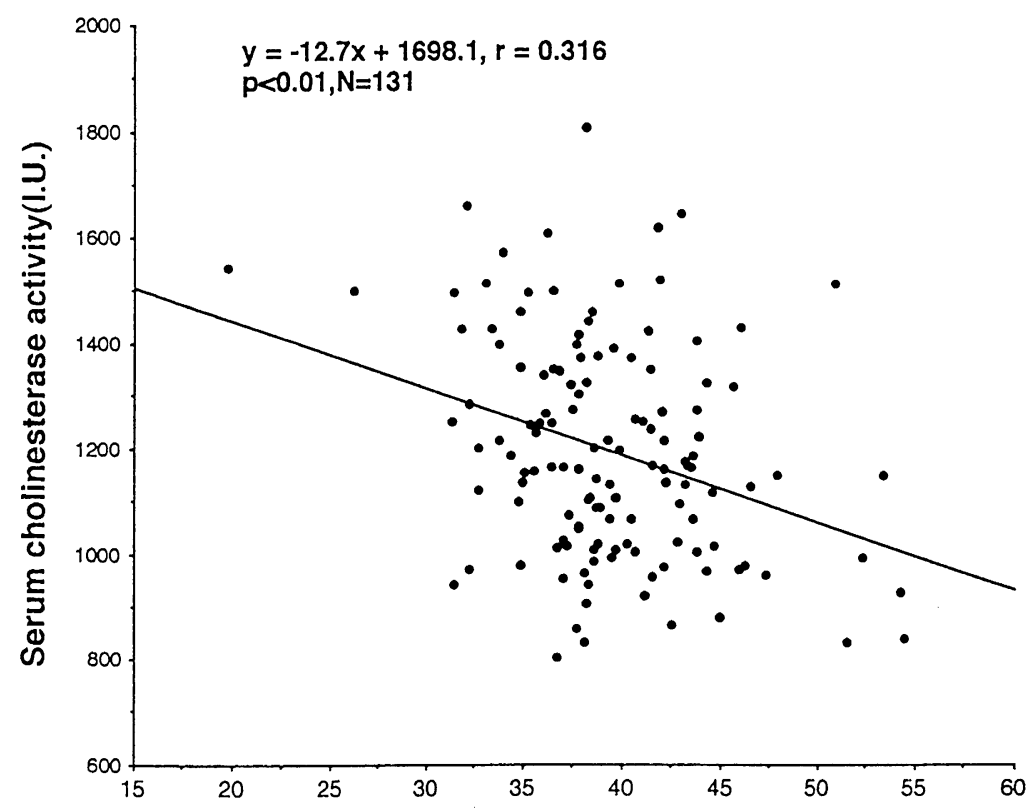

Energy expenditure/body weight( $\mathrm{kcal} / \mathrm{kg})$

Fig. 2 Relationships between serum cholinesterase activity and energy expenditure/body weight 
beverages more than once a week, but there was also no significant difference between the serum cholinesterase activity levels of the subjects who and did not drink alcohol.

With regard to body weight, the groups with a BMI of over 22.0 had significantly high serum cholinesterase activity levels than those with a BMI of less than 22.0. The serum cholinesterase activity level showed significant positive correlations with BMI $(\mathrm{r}=0.327, \mathrm{p}<0.001)$ and body weight $(r=0.199, p<0.01)$.

7) The relationship between serum cholinesterase and physical activity

Fig. 2 shows the correlations between serum cholinesterase activity and energy expenditure per $\mathrm{kg}$ body weight. The group that showed the highest serum cholinesterase activity level was associated with the lowest energy expenditure per $\mathrm{kg}$ body weight $(\mathrm{r}=-0.316, \mathrm{y}=1698.1+12.7 \mathrm{x}, \mathrm{p}<$ $0.01)$.

2. Effect of physical exercise on the serum cholinesterase activity level

Exercise at 30,50 and $70 \% \dot{\mathrm{VO}}_{2 \max }$ may produced a significant increase in serum cholinesterase activity $(\mathrm{p}<0.05)($ Table 7$)$. The mean percentage increases over initial

Table 7 Serum cholinesterase activity before and after exercise

\begin{tabular}{|c|c|c|c|}
\hline \multirow{2}{*}{ Groups } & \multicolumn{3}{|c|}{ Serum cholinesterase activity (I.U.) } \\
\hline & & Mean & S.D. \\
\hline \multirow{2}{*}{$\begin{array}{c}\text { Group A } \\
30 \% \dot{V}_{2} \text { max }\end{array}$} & Pre & $1,001.6$ & $113.2^{*}$ \\
\hline & Post & $1,133.7$ & 151.1 \\
\hline \multirow{2}{*}{$\begin{array}{c}\text { Group B } \\
50 \% \dot{\mathrm{VO}}_{2} \text { max }\end{array}$} & Pre & $1,137.6$ & $221.5^{*}$ \\
\hline & Post & $1,367.6$ & 296.3 \\
\hline \multirow{2}{*}{$\begin{array}{c}\text { Group C } \\
70 \% \dot{\mathrm{VO}}_{2} \max \end{array}$} & Pre & 908.1 & $119.5^{*}$ \\
\hline & Post & $1,128.6$ & 182.5 \\
\hline
\end{tabular}

levels in groups $\mathrm{L}, \mathrm{M}$ and $\mathrm{H}$ were $13.3 \%$, $20.2 \%$ and $24.2 \%$, respectively. Serum cholinesterase activity did not change due to different intensities of exercise in these three groups.

\section{Discussion}

The life expectancy of the Japanese has now passed way beyond 70 years and "longevity" is expected by everyone as a matter of fact. The problem we have to face now is the "health status" associated with "longevity". With increased life expectancy, chronic diseases are called to our attention. For the major causes responsible for adult diseases, a "lack of physical exercise", "excesive nutritional intake", and "psychological stress" are cited. These 3 factors are deep-rooted in the modern civilization related to everyday life and it it is understood that adult diseases gradually a develop as a result of long-term accumulation of the effects of these 3 factors. For health promotion, therefore, it is necessary to eliminate this lack of exercise, consume appropriate quantities of nutrients, and ease psychological stress. By doing so the health of individuals with a potential to develop illness or in a stage preceding onset of a disease may be restored: or the health of a normal individual may be maintained as long as possible (Berkman et al., 1983)

In achieving the above-cited goals, objective data that represent the health status are needed. Blood is one biological fluid which can be collected easily and which holds a wealth of vital information concerning the status of one's health. With the recent advent of analytical instruments such as the autoanalyzer, it is now possible 
to determine many types of serum enzyme activities, serum lipid contents, and levels of inorganic trace elements simply and swiftly. Among them, the blood chemical analyses that are conducted in mass screening as are used to screen for diseases; but the majority of the data is the normal range and very little is being utilized in actual diagnosis.

In view of cost effectiveness, as well as reliability, the authors considered the use of these data that are in a normal range. As a start, they evaluated serum cholinesterase activity as an index of health status and its relationship with factors such as nutritional status, physical activity, and life style. As for the relationship with lipid metabolsim, high serum total cholesterol and triglyceride levels are often associated with a high serum cholinesterase activity. We consider two factors that are likely to be involved in an increase in serum cholinesterase activity: one is the effect of the accelerated velocity of lipid synthesis, the other is cholinesterase induction associated with enhanced lipid metabolism. The first is elaborated as follows: when augmented lipoprotein synthesis through a certain mechanism results in accelerated lipid turnover, cholinesterase is released from the lipoproteins that are being produced successively, thus raising the serum cholinesterase content. In this process, it is postulated that most of the cholinesterase is released from lipoproteins during the stage of LDL synthesis. This theory is supported by the fact that the cholinesterase level is normal in patients with II type secondary hyperlipidemia, in whom only the serum total cholesterol level is abnormally high but the TG level is generally in the acceptable range; while in patients with type IIB or IV with a high LDL level, the cholinesterase level is accentuated.

A high turnover rate for lipid metabolsim results in an accumulation of acyclcholine, which is the substrate for cholinesterase. The presence of an excess of this substance results in induction of cholinesterase in the liver and eventual increase in the cholinesterase content. This explains the second factor. The mechanism by which the serum cholinesterase activity level varies is extremely complex but it is certain that at least protein and lipid metabolism are related in the fluctuations of the level of this enzyme (Chu et al., 1978; Cucuian et al., 1975; Kutty et al., 1981; Ryhsnen et al., 1982). In the present study, the group with a high cholinesterase level also exhibited increases in the serum lipid contents (such as serum total cholesterol and triglyceride contents). In other words, it is recognized that lipid metabolsim affects the cholinesterase level that is in the normal range.

As for the relationship between the serum cholinesterase activity level and cardiovascular functions, the only (but not very outstanding) significant change we noted in the Korotkoff sound time.

For the relationship with nutrient intake, Hirai, et al (1976), determined the serum cholinesterase activity level as part of an epidemiological study for the screenning of organophosphate poisoning among citrus fruit farmers. Among the test subjects, they discovered many individuals with reduced serum cholinesterase activity levels and gave not only the effect of the organophosphate pesticides that were applied but also their nutritional intake as reasons for the 
low level of this enzyme. The same investigators reported that the intake of nutrients other than lipids and vitamin $\mathrm{B}_{2}$ (i.e., proteins, carbohydrates, $\mathrm{Ca}$, Vitamins $\mathrm{B}_{1}$ and C) as well as the overall caloric intake were lower in the group with intermediate cholinesterase deficiency in contrast to the group with the normal serum cholinesterase activity level.

As for the clinical data, Makino (1984) reported that fatigue and dietary factors had roles in fluctuations in the serum cholinesterase activity level. In the present study, we also noted that protein intake has a most profound statistical effect on the serum cholinesterase activity level, indicating the involvement of dietary factors. No reports have been found on the relationship between smoking and serum cholinesterase activity level. Neither did we find significant differences in the serum cholinesterase activity level of smoker and nonsmoker. We should note, howevre, that the test subjects were all around 20 years-old so the duration of smoking among the smoker is very short, thus making the effect of smoking negligible. Similarly, alcohol drinking did not produce any significant difference in the serum cholinesterase activity level. Again, the amount of alcohol consumed by individuals in this group was limited and their drinking history was extremely short, which may explain the absence of any notable effects. Ollenschlager (1989) reported a strong correlation between changes in the serum cholinesterase activity level and shifts in body weight. In the present study, we noted a tendency for higher serum cholinesterase activity level in the group with greater BMI. It has been known that the serum cholinesterase activity level rises in obese individuals and we suspect that the abnormality in the intrinsic lipid metabolism results in induction of serum cholinesterase activity. The mechanism responsible for changes in the serum cholinesterase activity level is complex and cannot easily be explained but it is known that exercise has systemic effects and causes changes in the levels of many enzymes in the muscles and liver (Dobreva et al., 1988). Conversely, changes in enzyme activities are directly related to the extent of exercise. It has been reported that the cholinesterase level rises subsequent to exercise (Pawlowska et al., 1985; Ryhanen et al., 1988; Shibata 1970). In a test where individuals were subjected to mild exercise in the present study, a statistically significant increase was recognized at each exercise intensity; and there was a tendency for a percentage increase in the enzyme level that was proportional to the intensity of exercise. However, the enzyme level was inversely related to the energy consumption (indicating the daily physical activity)/body weight, which is contrary to the results of the exercise test. We suspect the latent involvement of a confounding factor such as changes in body weight.

For the prevention of chronic diseases, it is necessary to establish a life style related to physical activities and nutrient intake (including the control body weight). To achieve this, a more effective program for health promotion must be implemented. The level of serum cholinesterase activity, it it can be utilized as a new health indicator, will be highly instrumental. Never before have we needed a medically reliable indicator so that we can offer nutritional 
and exercise guidance for health promotion. We must acquire an index to give specific instruction, rather than merely offering conceptual guidance on a balanced diet and physical activity.

\section{Conclusion}

1. The nutritional survery indicated a significant correlation between protein or vitamin $B_{2}$ intake and the serum cholinesterase activity.

2. Energy expenditure per kg body weight showed a significant correlation with the serum cholinesterase activity.

3. No significant relationship was found between the serum cholinesterase activity level and smoking or drinking.

4. The BMI was correlated with the serum cholinesterase activity.

5. Mild exercise regimens increased the serum cholinesterase activity level slightly.

These results suggest that the measurement of serum cholinesterase activity to develop as a new health indicator.

\section{References}

Berkman, L.F. and Breslow, L. (1983): Health and Ways of Living, 1-233, Oxford, University Press (New York)

Chu, M.I., Fontaine, P., Kutty, K., Murphy, D. et al. (1978): Cholinesterase in serum and low density lipoprotein of hyperlipidemic patients, Clin. Chim. Acta, 85, 55-59

Cucuianu, M., Popescu, T.A., Opincaru, A. \& Haragus, S. (1975): Serum pseudocholinesterase and ceruloplasmin in various types of hyperilipo proteinemia, Clin. Chim. Acta, 59 19-17

Dobreva, V. \& Kaloianova, F. (1988): Changes in the hexobarabital sleep and serum cholinesterase activity of rats treated with carbaryl, ProblKhing, 13, 109-114

Health Service Bureau (1989): Recommended Diet- ary Allowances for the Japanese, 4th Revision, 205, Daiichi Shuppan (Tokyo)

Higashi, H., Douya, S. \& Sagara, T. (1985): Toward the prevention of pesticide toxicity: A study of the predictive capability of erythrocyte acetylcholinesterase in farmers, Jpn. J. Health Hum. Ecol., 51, 78-91

Hirai, K. (1976): A study on the real state of serum cholinesterase activity levels in citru fruit area, Jpn. J. Rural Med., 25, 1-10

Hirai, K., Okuda, T., Shioakutsu, K., Muraoka, T., Okada, N. \& Torii, M. (1976): A epidemiological study on pseudocholinesterase in citrut fluit area with special reference to the relationship on serum lipids, Jpn. J. Rural Med., 29, 672-677

Higuchi, T., Tanada, S., Nakamura, T., ImaKki, M., Matsumoto, K. \& Miyoshi, T. (1994): Evaluation of serum lactate dehydrogenase activity for estimation of energy expenditure in human subjects, Ergonomics, 37, 389-397

Imaki, M., Miyoshi, T. \& Nakamura, H. (1993): Relationship of nutrient intake to serum enzyme activity, Jpn. J. Public Health, 40, 832-840

Kalow, W. \& Gebest, K. (1957): A methods for the detection of atypical forms of human serum cholinestearse: Determination of dibucaine number, Can. J. Bio. Phy. 35, 339

Kutty, K.M., Huang, S.N. \& Kean, K.T. (1981): Pseudocholinesterase in obesty: Hyper caloric diet induced changes in experimental obese mice, Experimentia, 37, 1141-1142

Makino, H. (1984): Assessment of nutritional status and clinical test, Rinsyou Kensa 28, 1741-1748

Nakamura, S. (1989): Serum cholinesterase activity, Nippon Rinsho, 598, 291-294

Ollenschlager, G., Schrappe, M., Steffen, M., Burger, B. \& Allolio, B (1989): Assessment of nutritional status - a part of routine clinical diagnosis: Cholinesterase activity as a nutritional indicators, Klin. Wocholinesterasenschr, 67, 1101-1107

Pawlowdka, D., Moniuszko-jankoniuk, J. \& Soltys, M. (1993): Parathion-methyl effect on the activity of hydrolytic enzymes after single physical exercise in rats, Pol. J. Pharmacol., 37, 629-638

Ryhanen, R., Kajovaara, M., Harri, M., Kalistekorhonen, E. \& Hanninen, O. (1988): Physical exercise affects cholinesterase and organophos- 
phate response, Gen. Pharmacol., 19, 815-818

Ryhsnen, R.J.J., Jauhainen, M., Laitinen, M.V. \& Puhakainen, E.V. (1982): Relationship between human serum cholinesterase, lipoproteins, and apolipoproteins, Biochemical Med., 28, 241-245

Shibata, S. (1970): Serum Enzyme, 253-361, Igaku Syoin (Tokyo)
Vihko, V., Salminen, A. \& Rajamaki, J. (1978): Oxidation and lysosomal capacity in skeletal muscle of mice after endurance training of different intensities,Acta physiol. Scand, 104, 74-81

(Received on October 31, 1994 ; Accepted on January 13, 1995)

\section{〔原 著〕}

\section{血清コリンエステラーゼ活性值に及ぼす多種の要因の評価}

\section{今木 雅英 大栗 美保 伊内 秋夫 \\ 吉田 幸恵 棚田 成紀}

成人病の予防対策について，体重管理を含めて 身体活動と摄取栄養の生活習慣を確立する必要が ある. そのために，より効果的な健康増進プログ ラムが実行されるための具体的な評価指標が必要 である．本研究では有機隣剤中毒や肝胆疾患の診 断に有用に用いられている血清コリンエステラー ゼ活性值が，新たな健康指標としての妥当性に関 する基礎的研究を行った。 以下血清コリンエステ ラーゼ活性值と関連する諸要因の関連性を検討し た結果である。

血清コリンエステラーゼ活性值の低值群と高値 群の血液生化学検査值の比較した結果, 高值群は, 低值群に較べて血清総コレステロール, 遊離コレ ステロール,トリグリセライド, リン脂質, $\gamma$-GTP が統計的に有意に高かった。

血清コリンエステラーゼ活性值の低値群と高值 群の血圧および血行動態を比較した結果, 高值群 は, 低值群に較べて脈波コロトコフ音時間のみが
統計的に有意に低かった。 血清コリンエステラーゼ活性值とエネルギー及 び摄取栄養素量の多変量解析の結果については, 蛋白質は正, ビタミン $\mathrm{B}_{2}$ は負の統計的に有意な標 準偏回帰係数を示した.

血清コリンエステラーゼ生活習慣の関係につい て，喫煙および飲酒とは関連性が認められなかっ た. BMI および体重との相関関係について, 統計 的に有意な正の相関関係が認められた。

エネルギー消費量/体重の高い群ほど,血清コリ ンエステラーゼ活性值が低值を示した。逆に，軽 度の運動付加を実施すると統計的に有意な上昇を 示し，運動強度が強くなるにしたがって，上昇率 も大きくなる傾向を示した。すなわち血清コリン エステラーゼ活性值は，摂取栄養および身体活動 の両方面から影響を受けていることが認められ た.

Key words: Serum cholinesterase activity, Nutrient intake, Exercise, Bodyweight, Life style 血清コリンエステラーゼ, 摂取栄養, 運動, 体重, 生活様式 